\title{
Dealing with anorexia nervosa among children and adolescents within a regional area
}

\author{
Benjamin Hansen, Paul Sutton, Allahna Heywood, Veronica Stanganelli, Annette Howe, Tanya Dodman \\ From 2015 ANZAED Conference: Riding the Waves to Recovery \\ Surfers Paradise, Australia. 21-22 August 2015
}

\section{Introduction}

Anorexia has the highest death rate of any psychiatric disorder (15-20\%). Research evidence suggests that inpatient treatment is correlated with expensive cost and poor long term outcomes.

\section{Objectives}

To evaluate the implementation of 10 years of familybased treatment for anorexia nervosa.

\section{Methods}

Patients were treated by an interdisciplinary team including: Paediatrician, Child Psychiatrist, social workers, psychologists and nurses with relevant training in Maudsley model.

The average number of bed-days over the 10 year-period prior to the Maudsley approach was 102.8. The average number of patients admitted each year was 3.2 with average length of stay of 32 days per patient.

\section{Results}

The implementation of this approach has been dependent upon an excellent stakeholders' relationship. We achieved $77 \%$ reduction in the average number of bed-days; $37 \%$ reduction on the admissions, $62 \%$ less length of stay and long-term positive outcomes.

\section{Conclusions}

Family-based treatment appears to be the most efficacious treatment for Youth Anorexia Nervosa despite of the scarce resources within Mackay region.

Published: 23 November 2015

*Correspondence: vefstanganelli@gmail.com

CYMHS, Queensland Health, Mackay, Australia
doi:10.1186/2050-2974-3-S1-050

Cite this article as: Hansen et al:: Dealing with anorexia nervosa among children and adolescents within a regional area. Journal of Eating Disorders 2015 3(Suppl 1):O50.
Submit your next manuscript to BioMed Central and take full advantage of:

- Convenient online submission

- Thorough peer review

- No space constraints or color figure charges

- Immediate publication on acceptance

- Inclusion in PubMed, CAS, Scopus and Google Scholar

- Research which is freely available for redistribution 